\title{
Aktivitas Ekstrak Etanolik Daun Jambu Mete Terhadap Otot Pectoralis Thoracicus Ayam Jawa Super
}

\section{The Activity of Cashew Leaf Ethanolic Extract on Pecthoralis Thoracicus Muscle of Jawa Super Chicken}

\author{
Mawaddah $^{1}$, H. Setiawan ${ }^{2 *}$, dan H. T. S. S. G. Saragih ${ }^{1}$ \\ ${ }^{1}$ Laboratorium Struktur dan Perkembangan Hewan, Fakultas Biologi, Universitas Gadjah Mada \\ Jl. Teknika Selatan, Sekip Utara, Yogyakarta, 55281 - Indonesia \\ ${ }^{2}$ Laboratorium Biologi, Fakultas Sains dan Teknologi Terapan, Universitas Ahmad Dahlan \\ Tamanan Bantul, Daerah Istimewa Yogyakarta, 55166 - Indonesia \\ *Corresponding E-mail: haris.setiawan@bio.uad.ac.id
}

(Diterima: 18 Oktober 2019; Disetujui: 10 Desember 2019)

\begin{abstract}
ABSTRAK
Daun jambu mete memiliki senyawa bioaktif alami yang berpotensi sebagai promotor pertumbuhan ternak. Penelitian ini bertujuan untuk mempelajari efek suplementasi ekstrak etanol daun jambu mete dalam pakan terhadap peningkatan berat badan dan otot pectoralis thoracicus ayam jawa super. Penelitian ini menggunakan 90 ekor day old chick (DOC) ayam jawa super yang dipelihara selama 15 hari. Penelitian menggunakan rancangan acak lengkap dengan perlakuan penambahan ekstrak etanol daun jambu mete pada pakan basal sebanyak $0 \mathrm{~g} / \mathrm{kg}$ pakan (K); 1,25 $\mathrm{g} / \mathrm{kg}$ pakan (P1); 2,5 $\mathrm{g} / \mathrm{kg}$ pakan (P2); $5 \mathrm{~g} / \mathrm{kg}$ pakan (P3); $10 \mathrm{~g} / \mathrm{kg}$ pakan (P4); $20 \mathrm{~g} / \mathrm{kg}$ pakan (P5). Metode terdiri dari pembuatan ekstrak etanolik daun jambu mete, pembuatan pakan, pemeliharaan ayam dan pembuatan preparat jaringan otot (metode parafin). Parameter pengamatan otot terdiri dari pengukuran berat otot dan luas area miofiber. Hasil menunjukkan terdapat peningkatan berat badan pada $\mathrm{P} 3, \mathrm{P} 4$ dan $\mathrm{P} 5$ dibandingkan dengan kontrol $(\mathrm{P}<0,05)$. Berat otot pada $\mathrm{P} 5$ lebih tinggi dibandingkan dengan kontrol $(\mathrm{P}<0,05)$. Luas area miofiber otot pada $\mathrm{P} 3$ memiliki luas yang paling lebar dibandingkan dengan kontrol $(\mathrm{P}<0,05)$. Kesimpulan menunjukan bahwa suplementasi ekstrak etanol daun jambu mete pada pakan dapat meningkatkan berat badan dan otot pectoralis ayam jawa super.

Kata kunci: Pectoralis thoracicus, daun jambu mete, miofiber, Ayam Jawa Super
\end{abstract}

\section{ABSTRACT}

Cashew leaves have a natural bioactive composition as a growth promoter on livestock. This research aims to study the effects of supplementation of ethanolic cashew leaf extract in the diet to increase body weight and muscle pectoralis thoracicus of Jawa super chicken. This research used 90-day old chickens (DOC) Jawa super chickens which were kept for 15 days. The study used a completely randomized design with the addition of ethanolic cashew leaf extract on basal feed as much as $0 \mathrm{~g} / \mathrm{kg}$ of feed $(\mathrm{K}) ; 1.25 \mathrm{~g} /$ $\mathrm{kg}$ of feed (P1); $2.5 \mathrm{~g} / \mathrm{kg}$ of feed (P2); $5 \mathrm{~g} / \mathrm{kg}$ of feed (P3); $10 \mathrm{~g} / \mathrm{kg}$ of feed (P4); $20 \mathrm{~g} / \mathrm{kg}$ of feed (P5). The method consisted of ethanolic cashew leaf extract preparation, feed preparation, raising chickens and muscle tissue preparations (paraffin method). Parameter muscle observation consisted of measurements of muscle weight and myofiber area. The results showed that there was an increase in body weight at P3, P4 and P5 compared to controls $(P<0.05)$. Muscle weight at $P 5$ was higher compared to controls $(P<0.05)$. The area of muscle myofiber at $P 3$ had the widest area compared to the control $(P<0.05)$. The conclusion shows that supplementation ethanolic cashew leaf extract in feed can increase body weight and pectoralis muscle of super Javanese chicken.

Keywords: Pectoralis thoracicus, cashew leaf, myofiber, Jawa super chicken 


\section{PENDAHULUAN}

Daging ayam merupakan salah satu sumber protein hewani yang paling banyak dikonsumsi masyarakat Indonesia. Konsumsi daging ayam di Indonesia terus meningkat sejalan dengan pertumbuhan jumlah penduduk dan peningkatan pendapatan perkapita. Perkembangan konsumsi ayam di Indonesia periode tahun 2012-2016 mengalami stagnansi yang cenderung meningkat, dengan rerata sebesar $2,49 \%$ per tahun atau setara dengan rerata populasi pertahun sebesar 282,09 juta ekor (Muliany, 2016). Salah satu ayam lokal yang dikembangkan di Indonesia adalah ayam jawa super. Ayam jawa super merupakan ayam hasil persilangan ayam jantan kampung dengan ayam betina layer (Setiawan et al., 2018b). Jumlah produksi ayam jawa super yang tidak maksimal dibandingkan dengan ayam ras pedaging mendorong peternak dan peneliti dalam meningkatkan produktivitas dan kualitas ayam jawa super (Adibmoradi et al., 2006; Muliany, 2016). Peningkatan kualitas produksi didukung dengan suplementasi pada pakan seperti antibiotik dalam meningkatkan pertumbuhan.

Antibiotik merupakan salah satu promotor pertumbuhan yang umum digunakan oleh peternak untuk meningkatkan produktivitas ayam. Pada tahun 2006, penggunaan Growth Promotor Antibiotic (GPA) dilarang dinegara-negara Uni Eropa serta beberapa negara lainnya karena memiliki beberaoa efek negatif bagi manusia (Amad et al., 2011; Graham et al., 2007; Jacela et al., 2010). Penggunaan antibiotik sebagai GPA dapat mempengaruhi peningkatan resistensi antibiotik hewan ternak terhadap beberapa kelompok kontaminan, serta resistensi produk makanan terhadap patogen (Khan et al., 2017). Terdapat berbagai macam sumber alternatif yang dapat menggantikan GPA sintetis yang berperan sebagai promotor pertumbuhan hewan ternak. Beberapa alternatif seperti senyawa herbal pada tanaman berpotensi sebagai promotor pertumbuhan dan antibiotik alami yang tidak menimbulkan efek negatif seperti pada antibiotik sintetis (Amad et al., 2011). Berbagai jenis tanaman yang berpotensi sebagai antibiotik alami banyak ditemukan di Indonesia, salah satunya adalah tanaman jambu mete.

Jambu mete merupakan tanaman yang tumbuh di Indonesia dan memiliki berbagai manfaat terutama dalam bidang kesehatan. Ekstrak etanol daun jambu mete memiliki senyawa antioksidan seperti golongan dari kelompok senyawa fenol dan flavonoid (Ajileye et al., 2015). Kandungan senyawa tanin, saponin, resin, alkaloid dan flavonoid pada ekstrak daun jambu mete juga berfungsi sebagai antibiotik (Leitão et al., 2013; Varghese et al., 2013). Senyawa tersebut dapat menurunkan dan menghambat pertumbuhan bakteri patogen seperti gram-positif maupun gram-negatif yang tumbuh pada hewan ternak (Tan and Chan 2014). Rajput et al. (2013) membuktikan bahwa senyawa antibiotik pada herbal dapat melindungi permukaan vili pada usus halus dari serangan patogen, sehingga meningkatkan penyerapan nutrisi pada pakan ayam. Penyerapan nutrisi pakan yang baik dapat meningkatkan performa pertumbuhan ayam sehingga manghasilkan produktifitas ayam yang unggul.

Salah satu parameter untuk mengukur pertumbuhan ayam adalah perolehan berat badan ayam dan performa pertumbuhan otot, terutama pada otot Pectoralis thoracicus. Peningkatan berat otot merupakan hasil dari hipertrofi otot yang terjadi pada anak ayam pasca menetas. Pertumbuhan hipertrofi otot dilakukan dengan meningkatkan kapabilitas sintesis protein dari miofiber dengan bantuan mionuklei tambahan. Berat otot ayam yang selalu meningkat menunjukan adanya peningkatan kapabilitas sintesis protein di dalam sel (Petracci and Berri, 2012). Penyerapan nutrisi yang baik dengan bantuan antibiotik alami dari herbal dapat meningkatkan pertumbuhan massa otot ayam (Saragih et al., 2017). Berdasarkan latar belakang tersebut, penelitian bertujuan untuk mengetahui tingkat efektivitas ekstrak daun jambu mete dalam mempercepat peningkatan 
berat badan ayam serta pertumbuhan otot Pectoralis thoracicus ayam jawa super.

\section{METODE}

\section{Kode Etik}

Penelitian ini menggunakan prosedur baku dan telah mendapatkan sertifikasi keterangan kelaikan kode etik dari Laboratorium Penelitian dan Pengujian Terpadu Universitas Gadjah Mada (LPPT UGM) dengan nomor sertifikasi 00005/04/ LPPT/II/2017.

\section{Pembuatan Ekstrak Etanol Daun Jambu Mete}

Daun jambu mete dikoleksi dan dikeringkan dioven dan diblender hingga menjadi serbuk. Serbuk daun jambu mete selanjutnya dilakukan maserasi menggunakan etano1 96\% dengan bantuan Rotary evaporator pada suhu $60^{\circ} \mathrm{C}$ selama 3 jam hingga etanol tervaporasi seluruhnya dan menghasilkan ekstrak berbentuk pasta.

\section{Pembuatan Pakan}

Pakan basal yang digunakan merupakan pakan basal ayam strater dengan konsentrasi protein sebanyak 21\% (Tabel 1). Pakan basal kemudian dicampurkan dengan ekstrak etanol daun jambu mete dengan konsentrasi $0 \mathrm{~g} /$ kg pakan $(\mathrm{K}) ; 1,25 \mathrm{~g} / \mathrm{kg}$ pakan $(\mathrm{P} 1) ; 2,5 \mathrm{~g} /$ $\mathrm{kg}$ pakan (P2); $5 \mathrm{~g} / \mathrm{kg}$ pakan (P3); $10 \mathrm{~g} / \mathrm{kg}$ pakan (P4); $20 \mathrm{~g} / \mathrm{kg}$ pakan (P5) dengan cara dilarutkan ke dalam air hangat.

\section{Aklimatisasi dan Pemeliharaan Ayam Jawa Super}

Sebanyak 90 ekor DOC ayam jawa super dibagi menjadi 6 kelompok perlakuan, masing-masing terdiri dari 15 ekor DOC yang dipelihara di dalam 6 kandang yang terpisah. Pemberian pakan dan minum dilakukan setiap hari, dua kali sehari pada pagi dan sore secara ad libitum. Aklimatisasi dilakukan selama 2 hari. Penerangan dilakukan dengan bantuan lampu pijar $\left(31-33^{\circ} \mathrm{C}\right)$. Ayam diberikan pakan selama 15 hari secara ad libitum. Pengukuran berat badan dilakukan setiap 3 hari sekali, yaitu pada umur $0,3,6,9,12$ dan 15 hari menggunakan timbangan digital.

\section{Pembuatan Preparat Histologi Otot Pectoralis Thoracicus}

Pemrosesan jaringan dilakukan setelah pembedahan pada umur 15 hari. Ayam di eutanasi dengan cara dislokasi pada bagian

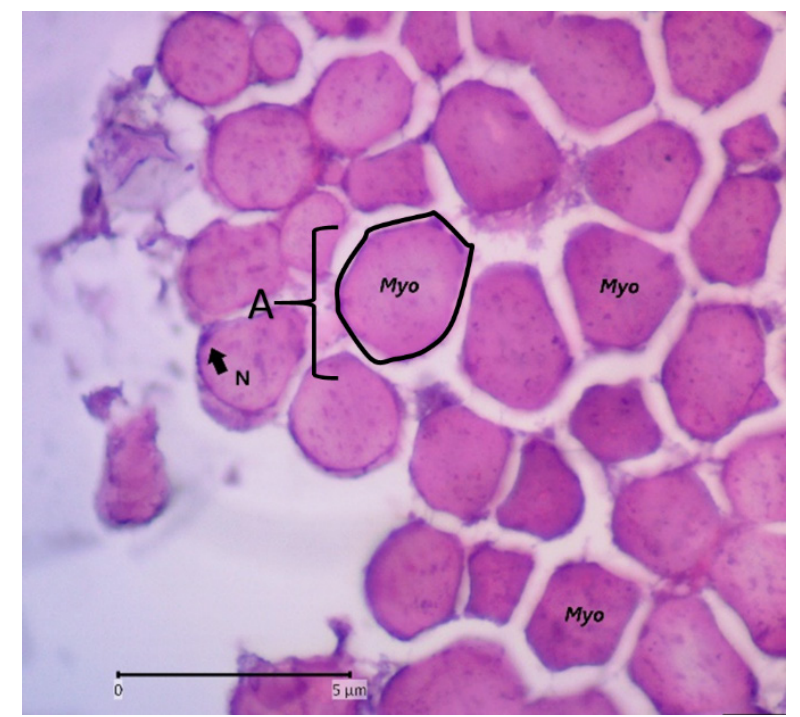

Gambar 1. Struktur melintang jaringan otot Pectoralis thoracicus

Keterangan: A (bagian luas area myofiber yang diukur), N (nukleus), Myo (Miofiber/serabut otot). Perbesaran 40x10, pewarnaan H.E. 
Tabel 1. Komposisi bahan pakan basal ayam Jawa Super starter

\begin{tabular}{lc}
\hline Komposisi Bahan Pakan & Viabel \\
\hline Berat Total (Kg) & 1,00 \\
Jagung (\%) & 63,53 \\
Soybean meal (\%) & 28,38 \\
Meat and bone meal (\%) & 4,70 \\
Crude palm oil (\%) & 0,95 \\
Dicalcium phsphate (\%) & 0,67 \\
premix mensa (\%) & 0,50 \\
Steam bonemeal (\%) & 0,45 \\
D,L-methionine (\%) & 0,23 \\
NaCl (\%) & 0,22 \\
CaCO $(\%)$ & 0,18 \\
L-lysine HCl (\%) & 0,10 \\
L-Threonine (\%) & 0,08 \\
Fintox (\%) & 0,01 \\
Dry Matter (\%) & 100,00 \\
Moisture (\%) & 14,9 \\
ME Poultry (Kcal/kg) & $3.447,176$ \\
Crude Protein (\%) & 21,00 \\
Crude Fat (\%) & 4,98 \\
Fiber (\%) & 1,57 \\
Lysine (\%) & 1,392 \\
Methionine (\%) & 0,767 \\
Threonine (\%) & 1,074 \\
Trytophan (\%) & 0,289 \\
Arginine (\%) & 1,575 \\
Isoleusine (\%) & 1,006 \\
Valine (\%) & 1,189 \\
Calcium (\%) & 1,034 \\
Phosphorus, total (\%) & 0,860 \\
Phosphorus, available (\%) & 0,460 \\
Sodium (\%) & 0,154 \\
Chloride (\%) & 0,241 \\
\hline
\end{tabular}

leher dan dilakukan pemotongan vena junggularis dengan menggunakan skalpel yang tajam. Kemudian dilakukan pembedahan dan koleksi organ otot Pectoralis thoracicus (PT). Otot PT bagian kanan dan kiri dikoleksi di bersihkan dari tulang dan ditimbang. Otot PT bagian kiri dipotong dengan ukuran $1 \mathrm{x} 1$ cm untuk dibuat preparat histologi dengan metode parafin pewarnaan Hematoxylineosin (HE). Jaringan otot PT diamati dengan mikroskop dengan perbesaran $10 \times 40$. Luas myofiber diukur dengan menggunakan software Image Raster. Pengukuran luas area myofiber dapat dilihat pada Gambar 1. 
Dokumentasi dilakukan dengan menggunakan optilab yang terintegrasi dengan software, dilakukan penyesuaian warna sehingga batas-batas endomysium terlihat dengan jelas. Myofiber yang representatif diambil 5 secara acak untuk ditentukan luasnya.

\section{Analisis Data}

Analisis data secara kuantitatif dengan uji one way ANOVA dengan taraf signifikansi $(\mathrm{P}<0,05)$, kemudian dilanjutkan dengan uji Least Significant Difference (LSD) dan Tukey menggunakan software SPSS statistics 20.0 untuk melihat tingkat signifikansi antar kelompok.

\section{HASIL DAN PEMBAHASAN}

\section{Berat Badan Ayam Jawa Super}

Peningkatan pertumbuhan ternak dapat diamati melalui peningkatan berat badan. Pemberian pakan dengan suplementasi tambahan berbahan dasar herbal dapat meningkatkan pertambahan berat badan ayam. Berat ayam yang diperoleh selama 15 hari dengan pemberian ekstrak etanol daun jambu mete dapat dilihat pada Tabel 2.

Pada perolehan berat badan ayam, hasil uji Anova memperlihatkan terdapat perbedaan secara signifikan antara perlakuan dengan kontrol $(\mathrm{p}<0,05)$ pada umur 6 sampai 15 hari. Tabel 2 menunjukkan hasil perolehan berat badan yang signifikan pada kelompok P3 $(109,7 \pm 9,48 \mathrm{~g})$ memiliki perbedaan secara signifikan dibandingkan dengan kelompok K $(96,5 \pm 11,42 \mathrm{~g})$ setelah pemberian ekstrak selama 15 hari.Data tersebutjugamenunjukkan bahwa pada kelompok P4 $(113,2 \pm 9,16 \mathrm{~g})$ dan P5 $(118,1 \pm 11,75 \mathrm{~g})$ memiliki pertambahan berat yang paling optimum jika dibandingkan kontrol. Penggunaan Phytogenic Feed Aditive (PFA) sebagai pengganti antibiotik promotor pertumbuhan atau yang biasa disebut GPA (Growth Promoter Antibiotic) pada pakan ayam dapat meningkatkan pertumbuhan berat badan (Lillehoj et al., 2018). Kandungan senyawa herbal pada PFA dari berbagai macam jenis tanaman menunjukkan peningkatan pertumbuhan ayam seperti peningkatan berat badan (Amad et al., 2011; Marcinčák et al., 2011). Penambahan ekstrak daun jambu mete sebagai PFA diduga dapat meningkatkan pertumbuhan ayam jawa super pada penelitian. Menurut Catoni et al. (2008) flavonoid dapat menstimulasi nafsu makan dan meningkatkan pencernaan ayam. Kandungan flavonoid pada ekstrak daun jambu mete diduga dapat mengoptimalkan penyerapan nutrisi pada pakan dengan memicu nafsu makan pada ayam jawa super.

Kandungan senyawa herbal pada tanaman dapat meningkatkan asimilasi pencernaan ayam dengan menstimulasi sekresi dari enzim dan hormon, sehingga berpengaruh positif terhadap pertumbuhan ayam (Hernandez et al., 2004; Amad et al., 2011). Flavonoid diketahui memiliki efek promotor pertumbuhan dengan cara meningkatkan regulasi hormon pertumbuhan (Growth Hormone) (Sherwood, 2013). Flavonoid memicu peningkatan konsentrasi insulin-like growth factor (IGF) pada hepar sehingga merangsang produksi growth hormon $(\mathrm{GH})$ dalam merangsang sintesis protein penyusun masa otot (Ouyang et al., 2016). Kamboh and Zhu (2013) menjelaskan bahwa isoflavonoid juga berperan dalam peningkatan sintesis protein pada masa otot. Kandungan senyawa flavonoid dan isoflavonoid pada ekstrak etanol daun jambu mete diduga dapat meningkatkan perolehan berat badan dengan meningkatkan pertumbuhan otot pada ayam jawa super dengan meningkatkan sintesis protein melalui peningkatan regulasi hormon pertumbuhan (GH).

Penelitian Setiawan et al. (2018b) memperlihatkan bahwa ekstrak etanol daun jambu mete dapat berperan sebagai antibiotik alami dengan melindungi saluran pencernaan seperti pada usus halus. Penggerusan vili pada usus halus dapat menyebabkan penurunan luas permukaan usus halus yang berdampak pada penyerapan nutrisi pada pakan ternak. flavonoid dan saponin pada daun jambu mete berfungsi sebagai antibiotik dengan 
Tabel 2. Data berat badan ayam jawa super yang diberi perlakuan ekstrak etanol daun jambu mete

\begin{tabular}{ccccccc}
\hline \multirow{2}{*}{ Umur } & \multicolumn{7}{c}{ Rataan $(\mathrm{g}) \pm \mathrm{SD}$} \\
\cline { 2 - 7 } & Kontrol & $\mathrm{P} 1$ & $\mathrm{P} 2$ & $\mathrm{P} 3$ & $\mathrm{P} 4$ & $\mathrm{P} 5$ \\
\hline 0 & $37,0 \pm 3,53$ & $36,8 \pm 3,67$ & $37,1 \pm 2,26$ & $36,8 \pm 3,64$ & $36,3 \pm 2,26$ & $36,2 \pm 1,75$ \\
3 & $42,4 \pm 6,98$ & $39,3 \pm 6,50$ & $39,6 \pm 4,45$ & $40,5 \pm 4,22$ & $41,1 \pm 4,01$ & $40,8 \pm 4,52$ \\
6 & $52,2 \pm 4,10^{\text {ab }}$ & $55,3 \pm 5,50^{\mathrm{b}}$ & $46,6 \pm 5,78^{\mathrm{a}}$ & $53,3 \pm 3,97^{\mathrm{b}}$ & $55,2 \pm 4,66^{\mathrm{b}}$ & $54,4 \pm 5,50^{\mathrm{b}}$ \\
9 & $59,5 \pm 7,32^{\mathrm{b}}$ & $61,4 \pm 5,15^{\text {ac }}$ & $51,2 \pm 6,60^{\text {a }}$ & $63,0 \pm 2,91^{\mathrm{bc}}$ & $67,7 \pm 5,60^{\mathrm{bc}}$ & $68,1 \pm 7,67^{\mathrm{c}}$ \\
12 & $80,4 \pm 14,17^{\text {ab }}$ & $88,0 \pm 13,98^{\mathrm{bc}}$ & $68,1 \pm 13,08^{\mathrm{a}}$ & $90,2 \pm 14,37^{\mathrm{bc}}$ & $88,7 \pm 7,39^{\mathrm{bc}}$ & $100,3 \pm 8,30^{\mathrm{c}}$ \\
15 & $96,5 \pm 11,42^{\mathrm{a}}$ & $94,5 \pm 13,75^{\text {ab }}$ & $84,6 \pm 18,43^{\mathrm{a}}$ & $109,7 \pm 9,48^{\mathrm{bc}}$ & $113,2 \pm 9,16^{\mathrm{c}}$ & $118,1 \pm 11,75^{\mathrm{c}}$ \\
\hline
\end{tabular}

Keterangan: K (ekstrak 0 g/kg pakan); P1 (1,25 g/kg pakan); P2 (2,5 g/kg pakan); P3 (5 g/kg pakan); P4 (10 $\mathrm{g} / \mathrm{kg}$ pakan); P5 (20 g/kg pakan). SD = Simpangan baku.

a,b,c Huruf superskript menandakan berbeda nyata, huruf kecil $\mathrm{p}<0,05$.

cara melindungi vili dari penggerusan akibat serangan bakteri patogen, sehingga ketersediaan nutrien dapat dipenuhi untuk pertumbuhan yang maksimal.

\section{Pertumbuhan Otot Pectoralis Thoracicus}

Peningkatan masa otot ayam dapat dipengaruhi oleh nutrisi pada pakan ternak. Pakan ternak yang ditambah dengan PFA dapat meningkatkan pertumbuhan otot sehingga dapat memperbaiki performans pertumbuhan ayam (Saragih et al., 2017). Parameter kualitas otot terdiri dari berat dan luas area miofiber otot ayam jawa super. Berat otot menunjukan bahwa pada kelompok perlakuan yaitu P3 $(5,34 \pm 0,55 \mathrm{~g}), \mathrm{P} 4(5,73 \pm 0,40 \mathrm{~g})$, dan P5 $(6,27 \pm 0,53 \mathrm{~g})$ memiliki berat yang lebih tinggi $(\mathrm{P}<0,05)$ dibandingkan dengan kontrol $(4,23 \pm 0,63 \mathrm{~g})$. Hasil pengamatan luas area miofiber menunjukkan perolehan luas area miofiber pada P3 $\left(3,80 \pm 1,00 \mu \mathrm{m}^{2}\right)$ lebih tinggi pada dibandingkan dengan kontrol $(1,04 \pm 0,28$ $\left.\mu \mathrm{m}^{2}\right)(\mathrm{p}<0,05)$. Peningkatan luas area myofiber pada otot mempengaruhi perkembangan berat otot ayam jawa super dengan hasil luas area miofiber pada kelompok perlakuan lebih besar (Tabel 3) dibandingkan dengan kontrol.

Pertumbuhan hipertrofi pada otot didukung oleh proliferasi sel satelit pada jaringan otot. Sel satelit berproliferasi dan berfusi dengan miofiber untuk meningkatkan jumlah dan menggandakan DNA dalam mendukung hipertrofi. Kandungan nutrisi pada pakan dapat mempengaruhi sel satelit pada ayam dalam melakukan hipertrofi pada otot (Daughtry et al., 2017). Menurut Harding et al. (2016) sel satelit pada otot dada (pectoralis thoracicus) lebih sensitif terhadap stimulus eksternal dibandingkan dengan sel satelit pada Biceps femoris. Diduga bahwa ekstrak etanol daun jambu mete dapat merespon stimulus otot dada dalam menunjang pertumbuhan otot yang ditandai dengan peningkatan berat otot dan luas area myofiber.

Pertumbuhan masa otot ayam didukung oleh stimulus hormon GH dengan mediasi oleh IGF-I. Infusi dari IGF-I memiliki efek hipertofik pada sel otot baik menggunakan hewan model maupun sel kultur (Velloso, 2008). Liu et al. (2008) melaporkan bahwa kandungan senyawa pada ekstrak herbal dapat meregulasi hormon dan protein terkait seperti IGF-I, IGF-IR (Reseptor IGF-I) dan IGF-binding protein yang dalam memicu pertumbuhan. Senyawa flavonoid pada herbal dapat meningkatkan konsentrasi serum IGF-I, termasuk peningkatan ekspresi gen mRNA IGF-I pada hepar sehingga menstimulus perkembangan jaringan otot atau myofiber.

Penelitian Jingga et al. (2019) memperlihatkan bahwa senyawa flavonoid pada daun jambu mete dapat meningkatkan sistem imun pada ayam jawa super. Ekstrak etanol daun jambu mete dapat meningkatkan proliferasi sel pada organ limfa dan bursa fabrisius sehingga berfungsi sebagai 
JPI Vol. 22 (1): 80-88

Tabel 3. Data berat otot dan luas area miofiber ayam jawa super yang diberi perlakuan ekstrak etanol daun jambu mete

\begin{tabular}{lcccccc}
\hline \multirow{2}{*}{ Parameter } & \multicolumn{5}{c}{ Rataan \pm SD } \\
\cline { 2 - 7 } & Kontrol & P1 & P2 & P3 & P4 & P5 \\
\hline Berat Otot $(\mathrm{g})$ & $4,23 \pm 0,63^{\mathrm{a}}$ & $4,43 \pm 0,47^{\mathrm{ab}}$ & $3,49 \pm 0,46^{\mathrm{a}}$ & $5,34 \pm 0,55^{\mathrm{bc}}$ & $5,73 \pm 0,40^{\mathrm{c}}$ & $6,27 \pm 0,53^{\mathrm{c}}$ \\
$\begin{array}{l}\text { Luas Area Miofiber } \\
\left(\mu \mathrm{m}^{2}\right)\end{array}$ & $1,04 \pm 0,28^{\mathrm{a}}$ & $1,26 \pm 0,25^{\mathrm{a}}$ & $2,14 \pm 0,43^{\mathrm{b}}$ & $3,80 \pm 1,00^{\mathrm{d}}$ & $2,53 \pm 0,48^{\mathrm{b}}$ & $3,08 \pm 0,70^{\mathrm{c}}$ \\
\hline
\end{tabular}

Keterangan: K (ekstrak $0 \mathrm{~g} / \mathrm{kg}$ pakan); P1 (1,25 g/kg pakan); P2 (2,5 g/kg pakan); P3 (5 g/kg pakan); P4 (10 $\mathrm{g} / \mathrm{kg}$ pakan); P5 (20 g/kg pakan). SD = Simpangan baku.

a,b,c Huruf superskript menandakan berbeda nyata, huruf kecil $\mathrm{p}<0,05$.

imunomodulator pada hewan ternak. Imunitas yang baik dapat menyebabkan peningkatan penyerapan nutrisi, sehingga meningkatkan pertumbuhan pada ayam jawa super. Hirasaka et al. (2013) menjelaskan bahwa senyawa isoflavonoid dapat mencegah terjadinya inflamasi yang berkaitan dengan atropi otot. Kandungan flavonoid dan isoflavonoid pada daun jambu mete diduga mendukung pertumbuhan miofiber otot Pectoralis thoracicus serta memiliki potensi untuk mencegah terjadinya inflamasi yang berkaitan dengan atropi otot pada ayam.

Setiawan et al. (2018a) menyatakan bahwa kandungan senyawa flavonoid, tanin dan saponin pada daun jambu biji dapat melindungi lapisan mukosa lambung dan usus halus, sehingga dapat meningkatkan penyerapan nutrisi pada pakan ayam. Penelitian Setiawan et al. (2018b) juga memperlihatkan bahwa kandungan flavonoid pada ekstrak etanol daun jambu mete dapat meningkatkan penyerapan nutrisi pada pakan. Peningkatan penyerapan nutrien oleh usus halus dapat meningkatkan ketersediaan nutrien yang dibutuhkan miofiber dan sel satelit untuk melakukan pertumbuhan hipertrofi. Ekstrak etanol daun jambu mete diduga dapat meningkatkan pertumbuhan jaringan otot khususnya miofiber otot Pectoralis thoracicus, sekaligus meningkatkan perolehan berat badan ayam yang merupakan hasil dari pertumbuhan otot yang maksimal.

\section{KESIMPULAN}

Pada penelitian ini dapat disimpulkan bahwa suplementasi ekstrak etanol daun jambu mete pada konsentrasi $5 \mathrm{~g} / \mathrm{Kg}$ pakan dapat meningkatkan berat badan, berat otot serta luas area myofiber ayam jawa super.

\section{DAFTAR PUSTAKA}

Adibmoradi, M., B. Navidshad., J. Seifdavati, and M. Royan. 2006. Effect of dietary garlic meal on histological structure of small intestine in broiler chickens. The Journal of Poultry Science. 43:378-383.

Ajileye, O. O., E. M. Obuotor., E. O. Akinkunmi, and M. A. Aderogba. 2015. Isolation and characterization of antioxidant and antimicrobial compounds from Anacardium occidentale L. (Anacardiaceae) leaf extract. Journal of King Saud University 27(3): 244-252.

Amad, A. A., K. Männer., K. R. Wendler., K. Neumann, and J. Zentek. 2011. Effects of a phytogenic feed additive on growth performance and ileal nutrient digestibility in broiler chickens. Poultry Science. 90: 2811-2816.

Catoni, C., H. M. Schaefer, and A. Peters. 2008. Fruit of health : the effect of flavonoids on humoral immute response and food selection in frugivorus birds. The Journal of Functional Ecology. 
22(4): 649-654.

Daughtry, M. R., E. Berio., Z. Shen., E. J. R. Suess., N. Shah., A. E. Geiger, and E. R. Berguson. 2017. Processing and product: satellite cell-mediated breast muscle regeneration decreases with broiler size. Poultry Science. 96: 34573464.

Graham, J. P., J. J. Boland, and E. Silbergeld. 2007. Growth promoting in food animal production: an economic analysis. Public Health Report. 122(1): 79-87.

Harding, L. R., O. Halevy., S. Yahav, and S. G. Velleman. 2016. The effect of temperature on proliferation and differentiation of chicken skeletal muscle satellite cells isolated from different muscle types. Physiological Report. 4(8): e12770.

Hernandez, F., J. Madrid., V. Garcia., J. Orengo, and M. D. Megias. 2004. Influence of two plant extracts on broilers performance, digestibility, and digestive organ size. Poultry Science. 83: $169-174$.

Hirasaka, K., T. Maeda., C. Ikeda., M. Haruna., S. Kohno., T. Abe, and T. Nikawa. 2013. Isoflavones derivied from soy beans prevent MuRF1-mediated muscle atrophy in $\mathrm{C} 2 \mathrm{C} 12$ myotubes through SIRT1 activation. Journal of Nutritional Science and Vitaminology. 59: 317-324.

Jacela, J. Y., J. M. DeRouchey., M. D. Tokach., R. D. Goodband., J. L. Nelssen., D. G. Renter, and S. S. Dritz. 2010. Feed additives for swine: Fact sheets - prebiotics and probiotics, and phytogenics. Journal of Swine Health and Production. 18(3): 132-136.

Jingga, M. E.,H. Setiawan., A. Nuriliani, and H. T. Saragih. 2019. Biosupplementation of ethanolic extract of cashew leaf (Annacardium occidentale L.) to improve weight gain and immunity of jawa super chicken. Jurnal acta veterinaria indonesiana. 7(2): 57-65.
Kamboh, A. A. and W. Y. Zhu. 2013. Effect of increasing levels of bioflavonoids in broiler feed on plasma anti-oxidative potential, lipid metabolites, and fatty acid composition of meat. Poultry Science. 92: 454-461.

Khan, I., H. Zaneb., S. Masood., M. S. Yousaf., H. F. Rehman, and H. Rehman. 2017. Effect of Moringa oleifera leaf powder supplementation on growth performance and intestinal morphology in broiler chickens. J Anim Physiol Anim Nutr. 101(Suppl.1): 114-121.

Leitão, N. C. M. C. S., G. H. C. Prado., P. C. Veggi., M. A. A. Meireles, and C. G. Pereira. 2013. Anacardium occidentale L. leaves extraction via SFE: global yields, extraction kinetics, mathematical modeling and economic evaluation. The Journal of Supercritical Fluids. 78: 114-123.

Lillehoj, H., L. Yanhong., C. Sergio., E. Mariano., M. Fernandez., C. Fang., L. Ron., C. S. Oh, and C. G. Gay. 2018. Phytochemicals as antibiotic alternatives to promote growth and enhance host health. Veterinary Research. 49: 76.

Liu, G. M., Y. Wei., Z. S. Wang., D. Wu., A. G. Zhou, and G. L. Liu. 2008. Effects of herbal extract supplementation on growth performance and insulinlike growth factor (IGF)-I system in finishing pigs. Journal of Animal and Feed Science. 17: 538-547.

Marcinčák, S., P. Peter., Z. Nevijo., M. Mária., Š. Jana, and M. Dana. 2011. Effect of supplementation of phytogenic feed additives on performance parameters and meat quality of broiler chickens. Slovenian Veterinary Research. 48(1): 27-34.

Muliany, H. P. 2016. Outlook daging ayam: komoditas pertanian, subsektor peternakan. Jakarta, Pusat Data dan Sistem Informasi Pertanian Sekertariat Jendral Kementrian Pertanian. 
Ouyang, K., M. Xu., Y. Jiang, and W. Wang. 2016. Effect of alfafa flavonoids on broiler performance, meat quality and gene expression. The Journal of Canadian Animal Science. 96(3): 332341.

Petracci, M. and C. Berri. 2012. Poultry quality evaluation: quality attributes and consumer value. Chennai: Woodhead Publishing. Pp: 33-36.

Rajput, N., N. Muhammad., R. Yan., X. Zhong, and T. Wang. 2013. Effect of dietary supplementation of curcumin on growth performance, intestinal morphology and nutrients utilization broiler chicks. The Journal of Japan Poultry Science Association. 50: 44-52.

Saragih, T. S. G. S., M. F. Alawi., M. Rafieiy., I. Lesmana,danH.Sujadmiko.2017.Pakan aditif ekstrak etanol lumut hati meningkatkan pertumbuhan morfologi duodenum dan perkembangan otot dada ayam pedaging. J Veteriner. 18(4): 617- 623.

Setiawan, H., M. E. Jingga, and $\mathrm{H}$. T. Saragih. 2018a. The effect of cashew leaf extract on small intestine morphology and growth performance of Jawa Super Chicken. Veterinary World 11(8): 1047-1054

Setiawan, H., L. B. Utami, dan M. Zulfikar. 2018b. Serbuk Daun Jambu Biji Memperbaiki Performans Pertumbuhan dan Morfologi Duodenum Ayam Jawa Super. Jurnal Veteriner. 19(4): 554-567

Sherwood, L. 2013. Fisiologi Manusia Dari Sel ke Sistem. Edisi 8. EGC, Jakarta. 652-654 p.

Tan, Y.P. and E. W.C.Chan. 2014.Antioxidant, antityrosinase and antibacterial properties of fresh and processed leaves of Anacardium occidentale and Piper betle. Food Bioscience 6: 17-23.

Varghese, J., V. K. Tumkur., V. Ballal, and G. S. Bhat. 2013. Antimicrobial effect of Anacardium occidentale leaf extract against pathogens causing periodontal disease. Advances in Bioscience and Biotechnology. 4: 15-18.

Velloso, C. P. 2008. Regulation of muscle mass by growth hormone and IGF-I. British Journal of Pharmacology. 154(3), 557-568. 